\title{
Principles of $\mathrm{CO}_{2} /$ Erbium Laser Safety
}

\author{
Darrell J. Fader, MD, ${ }^{*}$ and Désirée Ratner, MD ${ }^{\dagger}$ \\ *Departments of Dermatology and Otolaryngology, University of Michigan Medical Center, Ann Arbor, Michigan, and \\ ${ }^{\dagger}$ Department of Dermatology, College of Physicians and Surgeons of Columbia University, New York, New York
}

\begin{abstract}
BACKGROUND. There are a variety of potential hazards with laser technology.

METHODS. A review of the literature.

OBJECTIVE. To summarize the potential hazards of $\mathrm{CO}_{2}$ and erbium laser technologies and the safety guidelines and equipment developed to minimize them.

RESULTS. Laser hazards can be divided into the following cate-
\end{abstract}

gories: mechanical, environmental, macrobiologic, microbiologic, and iatrogenic.

CONCLUSION. At the conclusion of this learning activity, the reader should be able to discuss the mechanical, environmental, macrobiologic, microbiologic, and iatrogenic hazards of resurfacing laser technology, the literature cited to support current safety guidelines, and the equipment developed to promote laser safety.
THE FIRST PRINCIPLE of laser therapy is laser safety. Prior to performing laser resurfacing with the various $\mathrm{CO}_{2}$ and erbium technologies available, the practitioner should be familiar with the assorted potential hazards of such technologies, literature cited to support current safety guidelines, and the equipment developed to promote safety. Laser hazards can be divided into the following categories to facilitate discussion: mechanical, environmental, macrobiologic, microbiologic, and iatrogenic.

\section{Mechanical Hazards}

A tightly concentrated beam of laser light requires a high-voltage system to supply the requisite power. Electrical shock risks are commensurate with other electronic equipment of similar output levels. Issues of appropriate laser installation, grounding, automatic shutoff features, and other safeguards should be addressed by a competent biomedical engineer or hospital laser technician. ${ }^{1,2}$ Before treating the patient, the laser surgeon should test the selected laser settings on a tongue depressor to confirm spot size, fluence, and pattern aimed at the intended location. ${ }^{3}$

\section{Environmental Hazards}

The main laser environmental hazard is fire. The most recent review of laser hazards reported an overall $7.3 \%$ incidence of fire-related events. ${ }^{4}$ Of particular

D. J. Fader, MD, and D. Ratner, MD, have indicated no significant interest with commercial supporters.

Address correspondence and reprint requests to: Darrell J. Fader, MD, Department of Dermatology, University of Michigan Health System, 1910 Taubman Center, Box 0314, Ann Arbor, MI 48109. importance is the risk of $\mathrm{CO}_{2}$ laser-induced fire in the presence of oxygen. Even $\mathrm{O}_{2}$ concentrations slightly greater than room air $(25 \%)$ can heighten the chance of igniting laser-touched objects. Supplemental oxygen should be avoided if possible during laser resurfacing. ${ }^{3}$ Laser ignition of endotracheal tubes has been reported both in the experimental laboratory and clinical operating room, and laryngotracheal burns have occurred. 3,5,6 Plastic polyvinyl chloride endotracheal tubes, including any associated rubber elements and oil-based lubricants, are combustible and potentially ignitable by the $\mathrm{CO}_{2}$ laser. ${ }^{7}$ It should be noted, however, that reports of $\mathrm{CO}_{2}$ laser-induced fires have predominantly occurred during oropharyngeal surgery. There is some evidence that cutaneous laser resurfacing in the presence of oxygen is safe, provided that the target area is free of combustible fuels and materials. ${ }^{8}$ Nevertheless, current recommendations include wrapping the endotracheal tube with wet gauze or aluminum foil during facial resurfacing. ${ }^{3,5}$ Alternatively, the use of metal tubes is safer, although such tubes usually have some component of plastic or rubber. ${ }^{9-11}$ Moistened towels and gauze absorb $\mathrm{CO}_{2}$ laser light and significantly decrease the chance of a fire if placed around the patient's head and neck for the duration of the procedure. $^{3}$

A misdirected laser beam may ignite drapes, clothing (of the patient, physician, or surgical assistant), or endotracheal tubes, as mentioned above. Unintended laser activation can be minimized by assigning an assistant the responsibility of maintaining the laser in standby mode when it is not in use. Laser foot pedals should be clearly labeled, easily accessible, and operated exclusively by the laser surgeon. An enclosed laser treatment room with explicit warning signs placed prominently at the entrance will limit bystander injuries. ${ }^{1,3}$ 


\section{Macrobiologic Hazards}

\section{Eyes}

The primary human hazard is ocular injury, accounting for almost $75 \%$ of laser accidents in one study. ${ }^{4}$ The eye is particularly vulnerable since laser beam collimation and the optical properties of the eye can culminate in an intense concentration of light on vital ocular structures. While lasers in the visible or nearinfrared spectrum (wavelengths 400-1400 nm) can damage the retina, lasers in the far-infrared regions, particularly the $\mathrm{CO}_{2}$ and erbium resurfacing devices, can injure the water-abundant cornea. ${ }^{1,3,12}$ Superficial corneal epithelium damage is quickly repaired, but corneal scarring can occur from deeper laser exposure with visual loss. ${ }^{1}$ Eye protection is consequently an essential part of periorbital laser resurfacing and consists of two components: patient safety and physician/ personnel safety.

Sundry corneal eye protectors are available to the patient, including plastic or metal eye shields. Ries et al. ${ }^{13}$ studied the effects of a continuous wave $\mathrm{CO}_{2}$ laser on six commercially available eye protectors. They demonstrated significant thermal damage in all of the plastic eye shields, in which the laser either burned through the shield or ignited it. The metallic shields were undamaged. Significant heat was generated when ultrapulsed $\mathrm{CO}_{2}$ light was directed at plastic corneal protectors. The Silktouch laser caused melting after a third pass, and the Coherent system generated a textured surface. Neither laser resulted in shield perforation after nine passes. ${ }^{13}$ Current recommendations for patient eye protection during $\mathrm{CO}_{2}$ periorbital laser resurfacing include a metal corneal shield (eg, Stefanovsky protector) placed in the patient's eyes over a layer of ophthalmic lubricating ointment with or without a topical anesthetic. ${ }^{3,13}$

All operating room personnel should wear protective eyewear. Ordinary optical glass blocks $\mathrm{CO}_{2}$ laser light, so virtually any eyewear is acceptable as long as side shields are present. Such eyewear is necessary to prevent injury from direct and reflected laser beams from the flat metallic surfaces of surgical instruments. A black coating over a roughened instrument surface appears to be most effective in reducing reflected laser light. ${ }^{2,14}$

\section{Skin}

Skin injury and accidental exposure occurred in $13.9 \%$ of incidents reported in the Rockwell study. ${ }^{4}$ Thermal injury from infrared laser energy can result in various degrees of erythema, blistering, or ulceration. Skin hazards rarely occur with exposures out of the immediate surgical field (ie, beyond the laser's focal zone) unless a flammable object is ignited by reflected light. ${ }^{1}$

\section{Teeth}

High-energy, long-exposure $\mathrm{CO}_{2}$ lasers have been shown to cause dental craters from melting and resolidification of enamel. At lower exposure levels, dental charring, cracking, and flaking were reported..$^{15}$ Intraoperative moist gauze or cottonoid protection of the patient's teeth is a reasonable precaution. ${ }^{3}$

\section{Microbiologic Hazards}

Another significant untoward consequence of $\mathrm{CO}_{2}$ laser-tissue interaction is the development of a smoke plume containing vaporized tissue fragments. Investigations of this debris have prompted practical and theoretical concerns regarding pulmonary and infectious risks.

\section{Pulmonary}

The effects of short-term exposure to large quantities of $\mathrm{CO}_{2}$ laser smoke were investigated in rat lungs. With increasing exposure, rats developed gross and microscopic pulmonary pathology consistent with congestive interstitial pneumonia and emphysema. ${ }^{16}$ No pathologic changes were observed in rats protected by a double-filtered smoke evacuation system consisting of a cartridge filter and an ultra-low-penetration air filter which trapped $0.1 \mu \mathrm{m}$ particles. A commercially available single filtration system (cartridge filter only), which filters particles to a size of $0.5 \mu \mathrm{m}$, was insufficient to fully protect rat lungs from laser exhaust, although emphysema was diminished and bronchial hyperplasia and inflammation were markedly reduced. ${ }^{17}$ A study ${ }^{18}$ of 32 plume samples during $\mathrm{CO}_{2}$ laser treatment for endometriosis found plume particles with a median aerodynamic diameter of $0.31 \mu \mathrm{m}$ (range 0.10 $0.80 \mu \mathrm{m})$, overlapping the size range of "lung-damaging dust." 19,20 While no cell-size particles (eg, the $7.5 \mu \mathrm{m}$ red blood cell) were found in the plume, minimizing the concern that viable tumor cells may be spread this way, the authors could not rule out the possibility of viral transmission. Standard surgical masks, which block particles down to $0.5 \mu \mathrm{m}$, thus are not good laser plume or dermabrasion protection. ${ }^{18}$ Furthermore, settling velocities of less than $0.3 \mathrm{~cm} / \mathrm{sec}$ are required for particles to deposit in the lungs. ${ }^{21} \mathrm{~A} 0.8 \mu \mathrm{m}$ particle settles at $0.0025 \mathrm{~cm} / \mathrm{sec}$. Particles smaller than that are not cleared from the air by settling, potentially extending the period of plume risk well beyond the duration of the procedure. ${ }^{21,22}$ 
An additional pulmonary hazard is the inhalation of vaporization-induced pyrolysis products containing carcinogens, such as nitrosamines and other toxic byproducts (benzene, formaldehyde, acrolein), all found in the $\mathrm{CO}_{2}$ laser plume in animal studies. ${ }^{1,23}$ Methods and equipment to address these risks will be discussed after infection hazards are considered below.

\section{Infections}

Based on earlier studies, $\mathrm{CO}_{2}$ laser vaporization of skin was originally thought to induce a sterile surgical field free of viable material. ${ }^{24-26}$ A subsequent report revealed intact keratinocytes and erythrocytes in the plume and splatter of $\mathrm{CO}_{2}$ laser treated tattoos and epitheliomas. ${ }^{27}$ Other work demonstrated viable bacterial spores in the plume and splatter in 5 of 13 laservaporized skin specimens treated at a relatively low irradiance $\left(<500 \mathrm{~W} / \mathrm{cm}^{2}\right) .{ }^{28}$ Viable bacteria were found in the $\mathrm{CO}_{2}$ laser plume in one study ${ }^{29}$ but not in another. ${ }^{30}$ Laser cutting with the $\mathrm{CO}_{2}$ and erbium systems was found to transport yeasts and bacteria from the skin surface to the depths of laser-formed craters, although some organism damage was noted. ${ }^{31}$ It remains to be shown whether the new ultrapulsed $\mathrm{CO}_{2}$ and erbium models used for skin resurfacing, with very high irradiances and short pulse durations, pose a clinical risk of bacterial or fungal transmission from patient to physician.

Initial reports a decade ago raised the possibility of viral disease transmission via laser debris. Garden et al. $^{32}$ recovered bovine papillomavirus (BPV) DNA from bovine warts (4 of 4 ) and human papillomavirus (HPV) DNA from human plantar warts (2 of 7) in the $\mathrm{CO}_{2}$ laser plume. This was confirmed in the laser plume of 5 of 8 patients with plantar warts ${ }^{33}$ and in the prefilter canisters of 13 of 65 patients with genital warts. ${ }^{34} \mathrm{Sev}$ enteen of 27 plume specimens from patients with recurrent respiratory papillomatosis proved to be HPV DNA-positive by polymerase chain reaction. ${ }^{35} \mathrm{HPV}$ was not identified in the plume of laser-treated laryngeal papilloma by the less sensitive Southern hybridization method. ${ }^{36}$ Continuous mode $\mathrm{CO}_{2}$ laser ablation with a high irradiance $\left(1667 \mathrm{~W} / \mathrm{cm}^{2}\right)$ could not demonstrate HPV viability or infectivity in plume-derived specimens from treated laryngeal papillomas. ${ }^{37}$ The ejecta from laser treated vulvar condylomas did not show intact viral organisms, and BPV ejecta and plume inoculated into animals did not confer viral infection. ${ }^{38}$ A survey of laser physicians revealed a similar overall incidence of warts in laser surgeons compared to the general population. When specific anatomic sites were considered, however, $\mathrm{CO}_{2}$ laser surgeons appeared to have a higher risk of acquiring nasopharyngeal verrucae, suggesting that inhalation of laser plume may have caused disease in the treatment of genital HPV. ${ }^{39}$ HPV DNA was not detected in the plume of Er:YAG treated nongenital warts by polymerase chain reaction. ${ }^{40}$

Baggish et al. ${ }^{44}$ demonstrated HIV proviral DNA in the plume of a continuous wave $\mathrm{CO}_{2}$ laser (irradiance $500 \mathrm{~W} / \mathrm{cm}^{2}$ ) in an in vitro design. Sterile tubing to collect vaporized laser debris was subsequently cut into segments and placed in culture for 28 days. While HIV p24 protein was detected in culture studies of 4 of 12 tube segments at 1-2 weeks, no sustained infection of HIV cultured cells was observed at day 28. In another investigation, simian immunodeficiency virus (SIV) was not found to be viable in the $\mathrm{CO}_{2}$ laser plume. ${ }^{42}$ Er:YAG laser vapors were shown in a more recent study, however, to contain infectious viral genes, infectious virus, and viable cells. ${ }^{43}$ While fragmentation of some viruses may occur at the time of direct laser impact, rendering some of them nonviable, it has been shown that even partial viral or oncogene sequences may have transforming potential, and may therefore potentially pose a significant health hazard to exposed personnel. ${ }^{44}$ While concerns have been raised regarding hepatitis $\mathrm{B}(\mathrm{HBV})$ infection from laser plumes, no studies have yet investigated this possibility. ${ }^{34}$

What does all of this mean? Even studies that revealed HPV DNA in the laser plume acknowledge that the risk of HPV transmission to the physician is probably very low. ${ }^{33-35,39}$ Infection transmission of HPV and HIV remains undocumented despite a decade of scrutiny. There are several potential explanations:

The inherent risk of plume infection is low. The amount of HPV DNA in the laser plume is very low and thus is unlikely to contain large quantities of infectious viral material. Contact with traumatized epithelium is probably necessary to disseminate HPV disease. ${ }^{35}$ Similarly, HIV requires lymphocyte or macrophage vectors to propagate, both of which are destroyed on laser impact. ${ }^{24-26,38}$ The concentration of HIV cells used in the Baggish et al. ${ }^{41}$ study was several times the number seen in patients with clinical acquired immunodeficiency syndrome and, as noted above, the isolated HIV DNA from the plume had limited biologic activity.

Preventative safety measures are working. The most important precautionary measure is the use of a smoke evacuation and filtering system, which is $98.6 \%$ efficient when the suction tip is placed $1 \mathrm{~cm}$ from the treatment site, yet rapidly falls to $50 \%$ when the tip is $2 \mathrm{~cm}$ from the treated area. ${ }^{45-47}$ For added convenience and compliance, newer generations of $\mathrm{CO}_{2}$ lasers are incorporating the smoke evacuator into the laser handpiece. ${ }^{3}$ A system with a volume capacity of 40 
cfm that filters particles larger than $0.1 \mu \mathrm{m}$ is desirable. ${ }^{48}$

The use of goggles to prevent splatter of material into the eyes, as well as to protect against laser beam injury, should be routine. Even a so-called high-efficiency laser mask can filter particles down to only 0.3 $\mu \mathrm{m}$, whereas HIV is $0.18 \mu \mathrm{m}$ in diameter and papillomavirus virions are $55 \mathrm{~nm}$. When a standard surgical mask was placed directly in the vapor path in front of the laser filter, HPV was successfully blocked, implying that virus-containing laser debris may exceed the mesh size of surgical masks. Alternatively, the mask's three webs may act as both mechanical and electrostatic filters, trapping particles several-fold smaller than the mask's pore size. ${ }^{33}$ Others argue that a substantial amount of inspired air occurs from the mask edges and subverts effective filtering. ${ }^{38}$ Surgical masks, however marketed, should be assumed to be inadequate filters of viral particles. Standardized tests of efficiency do not exist. Earlier mask evaluations were based on expelled bacterial counts, since the traditional purpose is to protect the patient from the mask wearer. ${ }^{47,49}$

It is too early to tell. The era of $\mathrm{CO}_{2}$ and erbium laser resurfacing is too new to ascertain infection risks, particularly with infections of prolonged latency such as HIV. ${ }^{50}$ The stigmata associated with HIV or HBV infection may retard efforts to report a laser-induced seroconversion. Which physician or hospital wants to publish the first case? How is it proven that the laser plume was the unequivocal risk factor? Thus, while the literature suggests a low risk of bacterial or viral transmission, conservative guidelines are routinely recommended and are reasonable, relatively easy to adopt, and do not adversely affect the surgeon's ability to perform the procedure and maximize results. An effective plume evacuator system is the cornerstone of microbiologic safety for the laser resurfacer. The use of gloves, gowns, masks, and the regular replacement of vacuum filters is advised. ${ }^{1-3,12-14,17,23-35,39,41,42,47,50}$

\section{latrogenic Hazards}

Perhaps the most important laser safety feature is the competence of the physician..$^{51-53}$ As a variety of medical and surgical disciplines expand their roles in performing laser resurfacing, a more standard credentialing system may emerge. Until then, it is recommended that a few basic resurfacing courses, including biophysics, safety, and tissue interactions, should be followed by a preceptorship, where an experienced laser surgeon is observed directly. Subsequently hands-on training under the direct supervision of a preceptor would be ideal. ${ }^{54}$ Periodic continuing medical educa- tion courses are necessary to keep pace with a field as rapidly evolving as this. ${ }^{51-53}$

\section{References}

1. Sliney DH. Laser safety. Laser Surg Med 1995;16:215-25.

2. Sliney DH, Wolbarsht ML. Safety with lasers and other optical sources. New York: Plenum, 1980.

3. Rohrich RJ, Gyimesi IM, Clark P, Burns AJ. $\mathrm{CO}_{2}$ laser safety considerations in facial skin resurfacing. Plast Reconstr Surg 1997;100: 1285-90.

4. Rockwell RJ. Laser incidents: a review of recent events. International Laser Safety Conference, 1997.

5. Meyers A. Complications of $\mathrm{CO}_{2}$ laser surgery of the larynx. Ann Otol Rhinol Laryngol 1981;90:132-34.

6. Hirshman CR, Smith J. Indirect ignition of endotracheal tubes during carbon dioxide laser surgery. Arch Otolaryngol 1980;106:639-41.

7. Hermens JM, Bennett MJ, Hirshman CA. Anesthesia for laser surgery. Anesth Analg 1983;62:218-29.

8. Wald D, Michelow BJ, Guyuron B, Gibb AA. Fire hazards and $\mathrm{CO}_{2}$ laser resurfacing. Plast Reconstr Surg 1998;101:185-88.

9. Fried MP, Mallampati SR, Liu FC, et al. Laser resistant stainless steel tracheal tube: experimental and clinical evaluation. Lasers Surg Med 1991;11:301-6.

10. Schramm VLJ, Mattox DE, Stool SE. Acute management of laserignited intratracheal explosion. Laryngoscope 1991;91:1417-26.

11. Nolt ML, Devos V. New endotracheal tube for laser surgery of larynx. Ann Otol Rhinol Laryngol 1978;87:554-57.

12. Leibowitz HM, Peacock GR. Corneal injury produced by carbon dioxide laser radiation. Arch Opthamol 1969;81:713-21.

13. Reis WR, Clymer MA, Reinisch L. Laser safety features of eye shields. Lasers Surg Med 1996;18:309-15.

14. Wood RLJ, Sliney DH, Basye RA. Laser reflections from surgical instruments. Lasers Surg Med 1992;12:675-78.

15. Porgel MA, Muff DF, Marshall GW. Structural changes in dental enamel induced by high energy continuous wave carbon dioxide laser. Laser Surg Med 1993;13:89-96.

16. Baggish MS, Elbakry M. The effects of laser smoke on the lungs of rats. Am J Obstet Gynecol 1987;156:1260-65.

17. Baggish MS, Baltoyannis P, Sze E. Protection of the rat lung from the harmful effects of laser smoke. Lasers Surg Med 1988;8:248-53.

18. Nezhat C, Winer WK, Fezhat F, Forrest D, Reeves WG. Smoke from laser surgery: Is there a health hazard? Lasers Surg Med 1987; 7:376-82.

19. Lipple CE. Characteristics of particles and particle dispersoids. Stanford Res Institute Journal 1961.

20. Albert PW. The complications of $\mathrm{CO}_{2}$ laser surgery in otolaryngology. Acta Otolaryngol (Stockh) 1981;91:375-81.

21. World Health Organization. Evaluation of exposure to airborne particles in the work environment. Geneva, Switzerland: World Health Organization, 1984.

22. Carlson SE. Physical properties of aerosols provided by dermabrasion. Arch Dermatol 1989;125:1637-43.

23. Sliney DH, Trokel SL, eds. Medical lasers and their safe use. Springer-Verlag: New York, 1992:1-225.

24. Mihashi S, Jako GJ, Incze J, Strony MS, Vaughan CW. Laser surgery in otolaryngology: interaction of $\mathrm{CO}_{2}$ laser and soft tissue. Ann N Y Acad Sci 1975;267:263-94.

25. Oosterhuis JW, Verschueren RCJ, Eibregen R, Oldhoff J. The viability of cells in the waste products of $\mathrm{CO}_{2}$ laser evaporation of Cloudman Mouse melanomas. Cancer 1982;49:61-67.

26. Bellina JH, Stjernholm RL, Kurpel JE. Analysis of plume emissions after papovavirus irradiation with the carbon dioxide laser. J Reprod Med 1982;27:268-70.

27. Matthews J, Newsom SWB, Walter NPJ. Aerobiology of irradiation with the carbon dioxide laser. J Hosp Infect 1985;6:230-33.

28. Walker NPJ, Matthews J, Newsom SWB. Possible hazards from irradiation with the carbon dioxide laser. Lasers Surg Med 1986;6: 84-86.

29. Byrne PO, Sisson PR, Oliver PD. Carbon dioxide laser irradiation of bacterial targets in vitro. J Hosp Infect 1987;9:265-73. 
30. Mullarley MB. The efficacy of the $\mathrm{CO}_{2}$ laser in sterilization of skin seeded with bacteria: survival at the skin surface and in plume emissions. Laryngoscope 1989;9:296-99.

31. Frenz M, Mathezloic F, Stoffel MH, et al. Transport of biologically active material in laser cutting. Lasers Surg Med 1988;8:562-66.

32. Garden JM, O'Banion MK, Shelnitz LS, et al. Papillomavirus in the vapor of carbon dioxide laser-treated verrucae. JAMA 1988;259: 1199-202.

33. Sawchuk WS, Weber PJ, Lowy DR, Dzubow LM. Infectious papillomavirus in the vapor of warts treated with carbon dioxide laser of electrocoagulation: detection and protection. J Am Acad Dermatol 1989;21:41-49.

34. Ferenczy A, Bergeron C, Richart RM. Human papillomavirus DNA in $\mathrm{CO}_{2}$ laser-generated plume of smoke and its consequences to the surgeon. Obstet Gynecol 1990;75:114-18.

35. Kashima HK, Kessis T, Mounts P, Shah K. Polymerase chain reaction identification of human papillomavirus DNA in $\mathrm{CO}_{2}$ laser plume from recurrent respiratory papillomatosis. Otolaryngol Head Neck Surg 1991;104:191-95.

36. Abramson AL, DiLorenzo TP, Steinberg B. Is papillomavirus detectable in the plume of laser-treated laryngeal papilloma? Arch Otoloryngol Head Neck Surg 1990;116:604-7.

37. Kunachak S, Sithisarn P, Kulapaditharom B. Are laryngeal papilloma virus-infected cells viable in the plume derived from a continuous wave carbon dioxide laser, and are they infectious? J Laryngol Otol 1996;10:1031-33.

38. Wisniewski PM, et al. Studies on the transmission of viral disease via the $\mathrm{CO}_{2}$ laser plume and ejecta. J Reprod Med 1990;35:1120-23.

39. Gloster HMJ, Roenigk RK. Risk of acquiring human papillomavirus from the plume produced by the carbon dioxide laser in the treatment of warts. J Am Acad Dermatol 1995;32:436-41.

40. Hughes PSH, Hughes AP. Absence of human papillomavirus DNA in the plume of erbium:YAG laser-treated warts. J Am Acad Dermatol 1998;38:426-28.
41. Baggish MS, Poeisz BJ, Joret D, Williamson P, Refai A. Presence of human immunodeficiency virus DNA in laser smoke. Lasers Surg Med 1991;11:197-203.

42. Starr JC, Kilmer SL, Wheeland RG. Analysis of the carbon dioxide laser plume for simian immunodeficiency virus. J Dermatol Surg Oncol 1992;8:297-300.

43. Ziegler BL, Thomas CA, Meier T, et al. Generation of infectious retrovirus aerosol through medical laser irradiation. Lasers Surg Med 1998;22:37-41.

44. Burns PA, Jack A, Neilson F, Haddow S, Balmain A. Transformation of mouse skin endothelial cells in vivo by direct application of plasmid DNA encoding the human T24 H-ras sequence. Oncogene 1991;6:1973-78.

45. Trevor M. Presence of virus in $\mathrm{CO}_{2}$ laser plumes raises infection concern. Hosp Infect Control 1987;14:166-67.

46. Mihashi S, Veda S, Hirano M. Some problems about condensates indured by $\mathrm{CO}_{2}$ laser irradiation. Tokyo, Japan: Fourth International Society for Laser Surgery, 1981.

47. Smith JP, Moss E, Bryant CJ, Fleeger AK. Evaluation of a smoke evacuator used for laser surgery. Laser Surg Med 1989;9:276-81.

48. Smith JP, Topmiller JL, Shulman S. Factors affecting emission collection by surgical smoke evacuators. Lasers Surg Med 1990;10:224-33.

49. Greene V, Vesley D. Method for evaluating effectiveness of surgical masks. J Bacteriol 1962;83:663-67.

50. Goldman L. Proposal to develop a detailed safety program for general/laser surgical patients infected with AIDS. Lasers Surg Med 1996;19:351-58.

51. Koch RJ. Laser skin resurfacing. What credentials are necessary? Dermatol Surg 1998;24:595-96.

52. Penoff J. Laser skin resurfacing. Ann Plast Surg 1996;36:392-93.

53. Field LM. Laser resurfacing hysteria. The media, the marketers, the companies, and us. Dermatol Surg 1998;24:684-86.

54. Field LM. Instructive interchanges and non-verbal surgical concepts. Dermatol Surg Product News 1998;14:7. 